\title{
Job Satisfaction of Contractual Teachers in Telangana - A study
}

\author{
Dr. T. Gopi ${ }^{1 *}$, Dr. K. Saidireddy ${ }^{2}$
}

\section{ABSTRACT}

In formal education teacher has a very important place in improvement of education. Teachers' role in society, in general and in higher education in particular has been changing with time but the importance of this position remains the same. The teacher is the pre-requisite of the success of all educational programmes. He/ She must have the ability to get satisfaction from his/her job. All educational programmes should inculcate good qualities in teacher so that he/she is in the best position to impart quality education to students. Development of the country requires a high rate of production and fullest possible utilization of both human as well as material resources. Nowadays, there is, however, a general feeling that the teachers do not have satisfaction in their job. There seems to be growing discontentment towards their job as a result of which standard of education is falling. Teachers are dissatisfied in spite of different plans and programs, which have been implemented to improve their job. Higher academic and professional qualification of the teachers, no doubt, can raise the standard of education as well as that of nation, but dissatisfied teachers, in spite of having a good and sound academic career and professional training, will do much harm than good because they will neither work whole heartedly nor will they try to contribute anything towards higher education. This paper is devoted to tracing out satisfaction and dissatisfaction of contractual teacher in Telangana aria.

Keywords: Job Satisfaction, Teachers, Telangana

“Job Satisfaction means liking of one's job and finding fulfillment in what you do. It combines an individual's feelings and emotions about the job and how the job affects their personal lives”, accords to Paul Specters (1985).

"If a person's work is interesting, pay is fair, promotional opportunities are good, supervisor is supportive and co-workers are friendly, then a situational approach leads one to predict that she/he is satisfied with her/his job”. In simple words if the pleasures associated with one's job outweigh the pains, there is some level of satisfaction, wrote Brief (1998).

\footnotetext{
${ }^{1}$ Research scholar in Commerce \& Business management, Kakatiya University. Warangal, Telangana

${ }^{2}$ Research scholar in Education, University College of Educstion, KakatiyaUniversity, Warangal, Telangana *Responding Author

(C) 2016 I T Gopi, K Saidireddy; licensee IJIP. This is an Open Access Research distributed under the terms of the Creative Commons Attribution License (http://creativecommons.org/licenses/by/2.0), which permits unrestricted use, distribution, and reproduction in any Medium, provided the original work is properly cited.
} 
In formal education teacher has a very important place in improvement of education. Teachers' role in society, in general and in higher education in particular has been changing with time but the importance of this position remains the same. The teacher is the pre-requisite of the success of all educational programmes. He/ She must have the ability to get satisfaction from his/her job. All educational programmes should inculcate good qualities in teacher so that he/she is in the best position to impart quality education to students.

Development of the country requires a high rate of production and fullest possible utilization of both human as well as material resources. Nowadays, there is, however, a general feeling that the teachers do not have satisfaction in their job. There seems to be growing discontentment towards their job as a result of which standard of education is falling. Teachers are dissatisfied in spite of different plans and programs, which have been implemented to improve their job. Higher academic and professional qualification of the teachers, no doubt, can raise the standard of education as well as that of nation, but dissatisfied teachers, in spite of having a good and sound academic career and professional training, will do much harm than good because they will neither work whole heartedly nor will they try to contribute anything towards higher education. The quality of education depends upon the quality of the teachers. Thus, the role of the teachers is very important in making the nation. If the teachers are versatile, intellectually enlightened, morally strong, emotionally balanced, socially and culturally advanced then the nation will have enlightened and excellent citizens. Job satisfaction plays a very important role in our everyday life, both for employees and organizations. Organizations have significant effects on all employees and how they feel at work is reflected in their jobs as well. Based on many studies, when employees are satisfied with their jobs they will be more committed to their employer and will be more productive. Job satisfaction impacts employee productivity, well-being and consequently impacts job quality.

Job satisfaction is a central variable in the study of organizational structure and theory, and can be considered a reflection of organizational functioning. Job satisfaction is the extent to which people like or dislike their jobs, and can be defined as feeling or affective reason an individual experience in a certain job role. The assessment of job satisfaction in many organizations has become an important practice to determine employee well-being. Teacher job satisfaction, while difficult to define, may be even more difficult to measure, Determinants of job satisfaction are known to vary according to gender, age, experience, and position, and defining job satisfaction for teacher involves many wide-ranging differences as to what contributes to job satisfaction(shann,1998. Job Satisfaction is a very important motivation factor which can play a vital role not only in motivating the teachers in classroom performance but also in entire development of an educational institution or organization. Generally, it is found that those teachers are happier with their profession, can perform better than others who are not satisfied with their profession. Socio-Economic condition is one of the most important predictor of job satisfaction of a teacher. 


\section{REVIEW OF LITERATURE}

The review of existing literature on the subject is of immense important for a research because it helps it helps him in many ways such as knowing the different areas and getting a clearer idea of one's research on various aspects of teacher's job satisfaction.

Nwachukwu Prince Ololube (2006) concluded that teacher related sources of job satisfaction seem to have a greater impact on teaching performance, as teachers are also dissatisfied with the educational policies and administration, pay and fringe benefits, material rewards and advancement.

Prof. Tripti Singh and Avantika Singh (2007) found that female members face more stress than the male members. Both genders with high work -family conflict and work-role stress have lower level of job satisfaction than those facing lower family conflict and work-role stress. Females facing high, family roles stress ${ }^{e e}$ experience higher job satisfaction than those facing low family role stressee.

Dr. Rajashree Gujarathi and Bhavna R Shetty (2012) suggested that the concept of human sigma within educational context, stating that a contended faculty is a source of student's satisfaction, but for this faculty need to be retained and satisfied.

Smt. Dipika R. Chaudhari (2012) suggested that teachers having favourable attitude towards their profession are generally successful, properly adjusted and well satisfied with their job.

Om Raj Katoch (2012) found that female college teachers are more satisfied with their job than male teachers and income per annum is an important factor impacting the level of job satisfaction. Previous study investigated different aspect of job satisfaction among the college teachers, this Study differs from those studies since it focus upon the comparison of job satisfaction between ad hoc basis teachers and regular basis teachers.

\section{Significance of the Study}

Teachers in education sector play vital role in the human development. They can only work with dedication when they will satisfy from their job. In this study, a step was undertaken in order to explore the level of job satisfaction among university teachers based on cadre, nature of job and work experience of university teachers. This step will provide initiative step for future research.

\section{Need for the study}

Satisfaction is an essential factor in any profession. Unless a man is satisfied with his job, it is very difficult for him to carry on his duties, honestly and efficiently. If he is not satisfied in the job, then he has to direct his attention to some other job. In this way his state of interest to the job is disturbed on account of satisfaction. The job satisfaction is important because one reason 
stems quite simple from value judgments. People spend a sizeable proportion of their walking lives in the work environment. From any minimally humanitarian point of view, we would want that proportion of their lives to be more or less pleasant, agreeable and fulfilling.

Job satisfaction is the result of various attitudes of an employee towards his job. These attitudes are related with specific factor such as salaries, service conditions, and advancement opportunities and other benefits. In case of job satisfaction of teacher there certain other factor, which are important such as intrinsic aspect and rapport with students, etc.,

\section{OBJECTIVES OF THE STUDY}

1. To study the job satisfaction of contractual teachers,

2. To study contractual teacher's Age, Gender, Marital status.

3. To study contractual teacher's Qualifications and their job satisfaction.

4. To drown up conclusions.

\section{Limitation of the study}

1. It is related to Age, Gender, Marital status, and educational qualifications only,

2. This study has limited only contractual teacher in Warangal, Khammam district.

\section{METHODOLOGY}

The data and information were collected through discussions and executed questionnaire and journals, Magazines and sample of the study consisted of contractual teachers male and female teachers of Government Degree and Post Graduate colleges in Warangal, Khammam districts,40 male and 20 female were selected as a sample for the study.52 itemed five pointed scale developed and used. Mean Standard deviation and $\mathrm{x}^{2}$ test was used to date analysis.

\section{Hypotheses}

1. There is no signification relationship between job satisfaction of contractual teacher and their age.

2. There is no signification relationship between job satisfaction of contractual teachers and their gender.

3. There is no signification relationship between job satisfaction of contractual teachers and their marital status.

4. There is no signification relationship between job satisfaction of contractual teachers and their educational qualification.

\section{DATA DISCUSSION}

The sample of present study constitute 60 contractual teachers as following manner

Table - 1, Gender wise sample

\begin{tabular}{|l|l|}
\hline Gender & No. of Teacher \\
\hline Male & 40 \\
\hline Female & 20 \\
\hline Total & 60 \\
\hline
\end{tabular}


Table -02, Sample Age wise

\begin{tabular}{|l|l|}
\hline Teacher s Age & No. of Teacher \\
\hline $30-35$ & 24 \\
\hline $35-40$ & 23 \\
\hline $40-$ above & 13 \\
\hline Total & 60 \\
\hline
\end{tabular}

Table - 03, Sample - Marital Status wise

\begin{tabular}{|l|l|}
\hline Marital Status of Teacher & No of Teacher \\
\hline Married & 30 \\
\hline Un Married & 30 \\
\hline Total & 60 \\
\hline
\end{tabular}

Table - 04, Sample Educational Qualifications wise

\begin{tabular}{|l|l|}
\hline Teachers Qualifications & No of Teachers \\
\hline P.G & 22 \\
\hline P.G +NET/SET & 28 \\
\hline P.G + PhD +NET & 10 \\
\hline Total & 60 \\
\hline
\end{tabular}

Source: Primary data compiled

The questionnaire has 52 items based on the factor of the job satisfaction. The scoring is on a five- point scale from 1 to 5 . For the response of "strongly Disagree" scoring is 1 and for "Disagree “ it is 2, for “ Undecided” it is 3 and for "Agree "scoring is 4 and for " Strongly Agree” It is 5. The respondent is instructed to tick only one of the each statement.

Table - 05, the degree of satisfaction accordance with score

\begin{tabular}{|l|l|}
\hline Score & Degree of job satisfaction \\
\hline $52-104$ & LOW \\
\hline $105-208$ & AVERAGE \\
\hline $209-260$ & HIGH \\
\hline
\end{tabular}

Source: Primary data compiled

Table - 06, The table shows the level of job satisfaction and Age

\begin{tabular}{|l|l|l|l|l|l|l|}
\hline \begin{tabular}{l} 
Age of $\begin{array}{l}\text { Agh } \\
\text { contractual } \\
\text { teachers }\end{array}$ \\
\cline { 2 - 6 }
\end{tabular} & Low Satisfaction & Average & High & Total & $\mathbf{X}^{2}$ & L.O.S \\
\hline $30-35$ & 05 & 17 & 02 & 24 & 11.1 & 0.05 \\
\hline $35-40$ & 05 & 09 & 09 & 23 & & \\
\hline $40-$ Above & 00 & 10 & 03 & 13 & & \\
\hline Total & 10 & 36 & 14 & 60 & & \\
\hline
\end{tabular}

Source: Primary data compiled 
There is no signification relationship between job satisfaction of contractual teachers and their age. The above table shows that the obtained $\mathrm{x}^{2}$ value is 11.1 , which is greater than to the value at 0.05 level. Hence the null hypothesis is rejected. From this we concluded that, there is no significance difference is exist on the opinion of contractual teachers with regarding to their job satisfaction and their age.

Table - 07, The table shows the level of job satisfaction and Gender

\begin{tabular}{|c|c|c|c|c|c|c|}
\hline \multirow{2}{*}{$\begin{array}{l}\text { Gender of } \\
\text { contractual } \\
\text { teachers }\end{array}$} & \multicolumn{6}{|c|}{ Job Satisfaction } \\
\hline & Low & Average & High & Total & $\mathrm{X}^{2}$ & L.O.S \\
\hline Male & 07 & 20 & 03 & 30 & 9.6 & 0.01 \\
\hline Female & 03 & 16 & 11 & 30 & & \\
\hline Total & 10 & 36 & 14 & 60 & & \\
\hline
\end{tabular}

Source: Primary data compiled

There is no signification relationship between job satisfaction of contractual teachers and their gender. The above table shows that the obtained $\mathrm{x}^{2}$ value is 9.6 which is greater than to the table value at 0.01 level. Hence the null hypothesis is rejected. From this we concluded that, there is no significance difference is exist on the opinion of contractual teachers with regarding to their job satisfaction and their gender.

Table - 08, The table shows the level of job satisfaction and marital status

\begin{tabular}{|c|c|c|c|c|c|c|}
\hline \multirow{2}{*}{$\begin{array}{l}\text { Marital status of } \\
\text { contractual } \\
\text { teachers }\end{array}$} & \multicolumn{6}{|c|}{ Job Satisfaction } \\
\hline & Low & Average & High & Total & $\mathrm{X}^{2}$ & L.O.S \\
\hline Married & 04 & 16 & 10 & 30 & 3.42 & N.S \\
\hline Un married & 03 & 16 & 11 & 30 & & \\
\hline Total & 10 & 36 & 14 & 60 & & \\
\hline
\end{tabular}

Source: Primary data compiled

There is no signification relationship between job satisfaction of contractual teachers and their age. The above table shows that the obtained $\mathrm{x}^{2}$ value is 3.42 , which is greater than to the table value at 0.05 level. Hence the null hypothesis is accepted. From this we concluded that, there is no significance difference is exist on the opinion of contractual teachers with regarding to their job satisfaction and their marital status. 
Job Satisfaction of Contractual Teachers in Telangana - A study

Table - 09, The table shows the level of job satisfaction and Educational Qualifications

\begin{tabular}{|c|c|c|c|c|c|c|}
\hline \multirow{2}{*}{$\begin{array}{l}\text { Educational } \\
\text { qualification of } \\
\text { contractual teachers }\end{array}$} & \multicolumn{6}{|c|}{ Job Satisfaction } \\
\hline & Low & Average & High & Total & $X^{2}$ & L.O.S \\
\hline P.G & 02 & 13 & 07 & 22 & \multirow[t]{4}{*}{11.67} & \multirow[t]{4}{*}{0.05} \\
\hline P.G + NET & 03 & 18 & 07 & 28 & & \\
\hline P.G +PhD + NET & 05 & 05 & 00 & 10 & & \\
\hline Total & 10 & 36 & 14 & 60 & & \\
\hline
\end{tabular}

Source: Primary data compiled

There is no signification relationship between job satisfaction of contractual teachers and their educational qualifications. The above table shows that the obtained $x^{2}$ value is11.67, which is greater than to the table value at 0.05 level. Hence the null hypothesis is rejected. From this we concluded that, there is no significance difference is exist on the opinion of contractual teachers with regarding to their job satisfaction and their educational qualifications.

\section{FINDINGS}

The study shows that salary and benefits, co-operation and support from higher level, professional development, job security, research support and facilities, support and freedom to chose the subjects to be taught and career advancement and promotion, found significant at $5 \%$ level of significance. It leads to rejection of null hypotheses. This study reveals that there is a significant difference in job satisfaction level of the contractual teachers and regular faculty on the above mentioned factors. As per the result, proper infrastructure is provided to faculty like book, lockers etc. to complete their job in well manner. As per the opinion of faculties, working condition not good, work load assigned to faculty and steps taken to empower and recognize the efforts done by the faculty is motivational for them.

1. These contractual teachers are being hired for a period of 10-11 months in an academic session instead of full year. So they remain unemployed for 2-3 months in a session. It becomes very difficult for them to run their family life during an unemployment period.

2. The contractual teachers which got relieving letters at the end of one session is not sure to get reemployed in the next session. The above mentioned concerns are major factors which abet dissatisfaction among contractual teachers. It is suggested that to counter the above raised concerns, no relieving at the end of academic session with further promise of employment for next academic session in order enhance the overall performance and satisfaction levels of these contractual teachers.

\section{CONCLUSION}

Salary is the direct benefit the college teachers get from their jobs. It is also one of the important satisfying factors. This study found a significant dissatisfaction among contractual teachers in this regard. Teachers feel that they are cheated, underpaid and made to work in insecure 
condition. The Contractual teachers are also human being with various needs to be satisfied and failure to have such needs satisfied leads to frustration, nonchalant attitude towards work and rebellion. It is suggested that there should be adequate educational policies and administration in term of reasonable payment and fringe benefits commensurate with the job contractual teachers do for them to be able to satisfy their basic needs in life. At least they should get basic pay which their regular counterparts are getting paid, to satisfy their basic needs. Job insecurity is found to be very significant cause of dissatisfaction among the ad-hoc faculty.

\section{REFERENCES}

Hayat, S., (1998), A Study of Organizational Climate, Job Satisfaction and Classroom Performance of College Teacher. (Unpublished $\mathrm{PhD}$ thesis), University of the Punjab, Lahore.

Natrajan, R., (2001), School Organizational Climate and Job-Satisfaction of Teachers. District Institute of Education and Training, Krishnagri: S. A. Journal of Indian Education . NCERT.

Srivastava, R., (1985), A Study of School Effectiveness in Relation to Organizational Climate (Unpublished D. Phil Thesis), Allahabad University India.

Mr. Ankur Goel, Dr. Priyank Sharma, Mr. Aditya Sharma, "Improving Job Satisfaction: An HR ", International Journal of Multidisciplinary Management Studies Vol. 2, Issue 4, April 2012 